\title{
KUSTA NEURAL PADA SEORANG LAKI-LAKI BERUSIA 37 TAHUN YANG DIDIAGNOSIS MELALUI ELEKTRONEUROMIOGRAFI
}

\author{
Monica Rosalind Kawilarang, Maria Patricia Dian Putri, Luh Made Mas Rusyati \\ Bagian/SMF Ilmu Kesehatan Kulit dan Kelamin \\ FK Universitas Udayana/RSUP Sanglah, Denpasar
}

\begin{abstract}
ABSTRAK
Kusta merupakan penyakit infeksi kronis yang disebabkan oleh bakteri Mycobacterium leprae. Transmisi kusta terjadi akibat kontak erat berkepanjangan antara seseorang yang rentan dengan pasien kusta multibasillar yang belum diterapi. Pada empat sampai 8\% kasus, gambaran klinis hanya terdapat keterlibatan saraf, tanpa lesi kulit dengan apusan sayat kulit negatif. Kondisi ini dikenal sebagai kusta neural. Baku emas penegakkan diagnosis adalah biopsi saraf. Ketika biopsi saraf sulit dilakukan, maka penemuan klinis, epidemiologis, dan perubahan elektroneuromiografi dianggap cukup untuk diagnosis kusta neural. Terapi disesuaikan kriteria WHO, dianggap tipe pausibasillar atau multibasillar bergantung saraf yang terkena. Seorang laki-laki, 37 tahun, datang dengan kelemahan pada tangan kanan sejak tiga tahun yang lalu. Delapan tahun yang lalu, pasien sekamar dengan penderita kusta yang belum diterapi. Pemeriksaan fisik dalam batas normal. Status dermatologis pada tangan kanan didapatkan claw hand. Pemeriksaan saraf didapatkan penebalan nervus ulnaris dextra, penurunan sensibilitas pada lateral tangan kanan, jari ke-4 dan ke-5. Pemeriksaan voluntary muscle test didapatkan kelemahan otot yang dipersarafi oleh nervus ulnaris dextra. Pemeriksaan monofilamen Semmes-Weinstein didapatkan warna ungu pada dorsum dan plantar manus dextra bagian lateral. Apusan sayat kulit dari kedua telinga, siku dan lutut tidak didapatkan basil tahan asam. Pemeriksaan elektroneuromiografi menunjukan neuropati tipe campuran pada nervus ulnaris kanan. Pasien didiagnosis sebagai kusta neural dengan cacat kusta tingkat 2 dan mendapat terapi multi-drug treatment untuk tipe pausibasillar.
\end{abstract}

Kata kunci: kusta, kusta neural, neuropati nervus ulnaris

\section{NEURAL LEPROSY IN 37-YEAR-OLD MAN DIAGNOSED BY ELECTRONEUROMYOGRAPHY}

\begin{abstract}
Leprosy is a chronic infectious disease caused by Mycobacterium leprae. Transmission of leprosy consists of prolonged close contact between susceptible and genetically predisposed individuals and untreated multibacillary patients. In about 4-8\% of the cases, the clinical presentation is exclusively nerve involvement, without any cutaneous lesions and negative skin smear, known as neural leprosy (NL). Nerve biopsy is the gold standard for diagnosis. When nerve biopsy is challenging to perform, the clinical and epidemiological findings and electroneuromyography alteration is accepted as sufficient criteria to diagnose NL. Neural leprosy therapy follows WHO regiment in accordance with the paucibacillary or multibacillary classification depends on the nerve involved. A 37-years-old man presented with progressive right-hand weakness and numbness since three years ago. Eight years ago, the patient was a roommate of an untreated leprosy patient. The general examination is within normal limit. Dermatology status on the right hand found claw hand. Nerve examination found thickening of the right ulnar nerve, decrease of sensibility on the lateral right hand, the 4th and 5th fingers. The voluntary muscle test found weakness on the muscle that contributed to the right ulnar nerve. Examination with Semmes-Weinstein monofilament results is purple. Slit skin smears from both ear lobes, elbows, and knees found no acid-fast bacilli. Electroneuromyography showed mixed type right ulnar neuropathy. The patient was diagnosed with pure neural leprosy with grade 2 impairment and treated with multi-drug treatment for paucibacillary type.
\end{abstract}

\section{Korespondensi:}

Key words: leprosy, neural leprosy, ulnar nerve neuropathy

Jl. Diponegoro No.1 Denpasar Bali, 80114

Tlp: 0361-257517

Email: monicakawilarang@gmail.com 


\section{PENDAHULUAN}

Kusta adalah penyakit infeksi kronis yang disebabkan oleh Mycobacterium leprae dengan predileksi saraf tepi dan kulit. Diagnosis ditegakkan berdasarkan pemeriksaan dermatologis dan neurologis pada pasien. Diagnosis dini sangat penting karena penatalaksanaan dini dapat mencegah disabilitas yang berdampak pada kehidupan sosial dan kerja individu, juga memengaruhi stigma akibat penyakit ini. Kusta merupakan penyakit kompleks dengan gambaran klinis sangat beragam. Kadang dengan keterlibatan saraf berupa anestesi dan deformitas yang lebih dominan, namun kadang dengan lesi kulit yang lebih dominan. Pada sekitar 4-8\% kasus, gambaran klinis berupa keterlibatan saraf dalam bentuk defisit atau penebalan saraf, tanpa lesi kulit, dengan apusan sayat kulit yang negatif dan tanpa kelainan lain. Hal ini dikenal dengan kusta neural. Kusta neural lebih sering ditemukan di India dengan insidens antara 5,5-17,7\% dari semua kasus kusta. Insidens kusta neural di Indonesia tidak diketahui. Dari data di RSUP Sanglah Denpasar pada tahun 2015-2017, tidak didapatkan kasus kusta neural. Kusta neural dapat secara efektif diterapi dengan multidrug treatment (MDT) untuk kusta. Biopsi saraf merupakan baku emas diagnosis. ${ }^{1-4}$ Berikut dilaporkan sebuah kasus kusta neural dengan disabilitas kusta tingkat 2 yang merupakan kasus jarang dan penting untuk diketahui cara menegakkan diagnosis serta terapi untuk mencegah kecacatan lebih lanjut.

\section{KASUS}

Seorang laki-laki, 37 tahun, dirujuk ke RSUP Sanglah Denpasar dengan kelemahan pada tangan kanan sejak tiga tahun yang lalu. Tidak ada riwayat penyakit sebelumnya. Riwayat trauma pada tangan atau siku disangkal, riwayat alergi disangkal. Pasien pernah berobat ke dokter spesialis saraf dua tahun yang lalu, mendapat antibiotik dan vitamin namun tidak membaik. Riwayat sosial pasien lahir dan besar di Manado. Pasien bekerja sebagai pegawai di kapal pelayaran Jepang sejak 10 tahun yang lalu, dengan ritme kerja satu tahun berlayar diikuti istirahat selama tiga bulan di Manado. Delapan tahun yang lalu, pasien pernah sekamar dengan teman kerja yang berasal dari Madura selama satu tahun, yang mengalami bercak-bercak putih di seluruh tubuh yang kemudian diketahui adalah kusta.

Pemeriksaan fisik menunjukkan dalam batas normal. Status dermatologis pada tangan kanan didapatkan claw hand. Pemeriksaan saraf didapatkan penebalan nervus ulnaris kanan, tidak ada nyeri tekan. Pada tes sensibilitas didapatkan penurunan sensibilitas pada kulit yang dipersarafi oleh nervus ulnaris kanan, yaitu tangan kanan bagian lateral, jari ke-4 dan ke-5. Pemeriksaan voluntary muscle test didapatkan kelemahan pada otot yang dipersarafi oleh nervus ulnaris kanan. Pemeriksaan sensorik dengan monofilamen Semmes-Weinstein didapatkan penurunan sensorik pada palmar dan dorsum manus dekstra bagian lateral yaitu monofilamen ungu ( $2 \mathrm{gm})$. Apusan sayat kulit dengan pewarnaan Ziehl-Neelsen pada kedua cuping telinga, siku dan lutut tidak ditemukan kuman basil tahan asam. Elektroneuromiografi menunjukkan neuropati tipe campuran pada nervus ulnaris kanan. Pemeriksaan laboratorium meliputi darah lengkap, fungsi hati, fungsi ginjal dan gula darah dalam batas normal.

Pasien direncanakan untuk biopsi saraf, namun masih sulit dilakukan. Pasien direncakan untuk tes serologis ELISA anti PGL-1, namun pasien menunda karena beberapa alasan. Pasien didiagnosis sebagai kusta neural dan cacat kusta tingkat 2. Pasien mendapat terapi multi-drug treatment untuk tipe pausibasillar, terdiri atas rifampisin $600 \mathrm{mg}$ satu kali sebulan, dapson $100 \mathrm{mg}$ satu kali sebulan dilanjutkan, dapson $100 \mathrm{mg}$ satu kali sehari, selama enam bulan. Pasien juga diberikan vitamin neurotropik B1, B6, B12 masing-masing satu kali sehari.

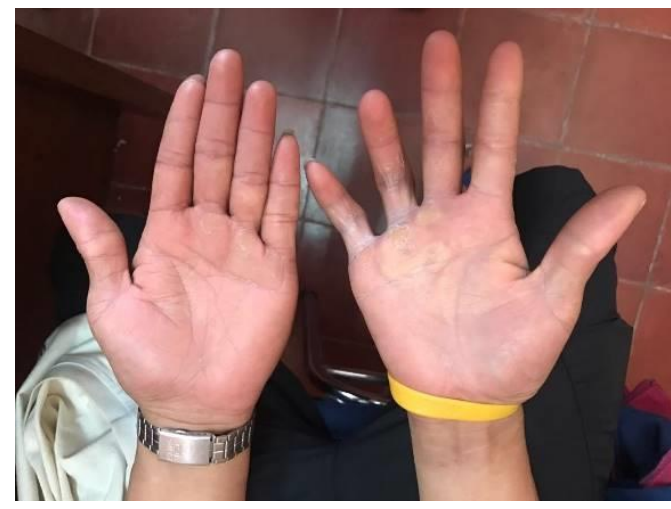

Gambar 1. Claw hand manus dextra

\section{DISKUSI}

Kusta disebabkan oleh Mycobacterium leprae yang merupakan bakteri tahan asam, berbentuk batang dan terutama menginfeksi makrofag dan sel Schwann. Mycobacterium leprae dapat tetap hidup hingga sembilan hari di lingkungan. Transmisi kusta terjadi karena kontak yang erat dan berkepanjangan antara seseorang yang rentan dengan pasien yang terinfeksi, secara inhalasi droplet melalui mukosa hidung. Transmisi dapat juga terjadi melalui erosi kulit namun jarang. Negara yang endemis kusta berlokasi di Asia Tenggara, Amerika, Afrika, Timur Tengah dan Mediterania Barat. Pada kasus dewasa, jumlah laki-laki lebih banyak dari perempuan dengan perbandingan 1,5 : 1. Meskipun kusta dapat terjadi pada segala usia, kebanyakan kasus terjadi pada usia kurang dari 35 tahun. Masa inkubasinya rata-rata 2-5 tahun pada tipe tuberkuloid dan 8-12 tahun pada tipe lepromatosa. Periode latensi antara paparan dan timbulnya gejala ratarata lima tahun untuk pausibasilar dan 10 tahun untuk 
multibasilar. Riwayat kontak merupakan faktor risiko kuat. Terdapat peningkatan risiko delapan sampai sepuluh kali lebih tinggi untuk tertular apabila orang serumah menderita kusta tipe lepromatosa, dan hanya dua sampai empat kali jika orang serumah menderita kusta tipe tuberkuloid. Pada $80 \%$ kasus baru kusta, terdapat riwayat kontak yang jelas dengan pasien kusta yang belum mendapat terapi. ${ }^{1-3}$ Pada kasus ini pasien adalah laki-laki dengan gejala kelemahan saraf sebelum usia 35 tahun. Perkiraan periode antara pajanan dari teman sekamar pasien hingga timbulnya gejala adalah lima tahun. Pasien tinggal di Indonesia yang merupakan negara endemis kusta.

Kusta ditandai dengan satu atau lebih tanda kardinal, yaitu bercak kulit hipopigmentasi atau eritematosa disertai penurunan sensoris, penebalan saraf tepi, dan terdapat bakteri tahan asam pada apusan sayat kulit atau biopsi. Penyakit ini sangat beragam dalam gambaran klinisnya, kadang dengan keterlibatan saraf, anestesi, dan deformitas yang lebih dominan namun kadang dengan lesi kulit yang lebih dominan. Pada kasus dengan gambaran klinis berupa keterlibatan saraf tanpa lesi kulit, dengan apusan sayat kulit yang negatif dan tanpa kelainan lain, disebut dengan kusta neural. Kusta neural paling sering berupa mononeuritis (keterlibatan satu saraf) yang terjadi pada $60 \%$ kasus. Bila lebih dari satu saraf terlibat dengan distribusi asimetris, dikenal sebagai mononeuritis multipleks, namun bila banyak saraf terlibat dengan distrubusi simetris disebut polineuropati atau polineuritis simetris. Saraf pada lengan lebih sering terkena. Sensasi suhu dan nyeri umumnya menurun lebih awal, namun pasien seringkali datang dengan kelainan sensorik dan motorik, rasa tebal, parestesi, dan nyeri. ${ }^{4}$ Pada kasus ini didapatkan penebalan saraf tepi, mononeuritis yang mengenai nervus ulnaris kanan yang seringkali didapatkan pada kusta.

Kusta secara primer merupakan penyakit yang menyerang saraf. Mycobacterium leprae akan menginfeksi sel Schwann di sekeliling serabut saraf dan akson. Neuropati pada kusta dapat menyebabkan disabilitas dan kecacatan. World Health Organization (WHO) mengklasifikasikan cacat akibat kusta menjadi 3 tingkat: tingkat 0 tidak didapatkan kelainan, tingkat 1 penurunan sensorik pada tangan dan kaki, dan tingkat 2 kelainan yang tampak. Neuropati dapat berkelanjutan, meskipun telah mendapat terapi efektif multi-drug treatment, dan kelainan sekunder dapat muncul akibat neuropati tersebut sehingga pasien dengan neuropati harus dievaluasi secara berkala. Penebalan saraf jarang ditemukan pada penyakit lain. Basil kusta akan menuju saraf melalui pembuluh darah perineural dan endoneural. Saat basil mencapai lamina basal endotel dan berada di endoneurium, basil ini akan memasuki makrofag dan sel Schwann secara selektif. Kerusakan saraf kemudian akan terjadi melalui beberapa mekanisme yaitu obstruksi pembuluh darah neural; vaskulitis pada pembuluh darah neural; mengganggu metabolisme sel Schwann, sehingga tidak mampu menunjang neuron; respons imunologis terhadap endotelium atau saraf; infiltrasi dan proliferasi M. leprae pada ruang endoneural dan perineural. ${ }^{5}$

Bakteri paling sering ditemukan di area kulit yang dingin, misalnya cuping telinga, bagian posterior siku, bagian anterior lutut, yang sering ditemukan penurunan sensibilitas. Pemeriksaan indeks bakteri harus dilakukan di area-area tersebut sebelum merujuk pasien untuk pemeriksaan lebih lanjut. Pada kasus ini apusan sayat kulit dari area cuping telinga, siku dan lutut tidak didapatkan bakteri basil tahan asam. ${ }^{6}$

Biopsi saraf merupakan baku emas diagnosis kusta neural. Namun pada beberapa kondisi, sulit dilakukan biopsi saraf karena beberapa alasan atau hasilnya tidak menunjukkan bakteri basil tahan asam. Temuan klinis dan epidemiologis bersama dengan perubahan elektroneuromiografi (ENMG) dianggap cukup untuk menegakkan diagnosis kusta neural. Hasil ENMG akan menunjukkan kelainan tipe aksonal, demielinasi atau tipe campuran. ${ }^{7,8}$ Pada kasus, dilakukan pemeriksaan ENMG sebagai alternatif penegakkan diagnosis yang non-invasif dibandingkan biopsi saraf, didapatkan hasil kelainan tipe campuran pada nervus ulnaris dextra. Pasien didiagnosis sebagai kusta neural dan disabilitas kusta tingkat 2.

Klasifikasi WHO untuk kusta pada tahun 1982 adalah pausibasilar atau multibasilar untuk tujuan terapeutik, berdasarkan hasil apusan sayat kulit dan jumlah lesi kulitnya. Menurut panduan National Leprosy Eradication Programme di India, ketika satu saraf terlibat dalam kusta neural, maka dianggap pausibasilar, jika lebih dari satu saraf terlibat, digolongkan multibasilar. Pada kasus ini, hanya satu saraf terlibat, sehingga dianggap sebagai pausibasilar. ${ }^{9}$ Pasien diterapi dengan multi-drug treatment untuk tipe pausibasilar yang terdiri atas rifampisin $600 \mathrm{mg}$ satu kali sebulan, dengan dapson $100 \mathrm{mg}$ satu kali sehari selama 6 bulan. Pasien juga diberikan vitamin neurotropik B1, B6, B12 masing-masing satu kali sehari.

\section{SIMPULAN}

Telah dilaporkan sebuah kasus yang jarang yaitu kusta neural dengan disabilitas kusta derajat 2. Diagnosis ditegakkan dari anamnesis, penemuan klinis, epidemiologis dan hasil elektroneuromiografi. Pasien diterapi dengan multi drug treatment untuk kusta tipe pausibasilar dan vitamin neurotropik.

\section{DAFTAR PUSTAKA}

1. Lastória JC, de Abreu MAMM. Leprosy: review of the epidemiological, clinical, and etiopathogenic aspects - Part 1. An. Bras. Dermatol. 2014;89:205-18.

2. Santos DF, Mendonca MR, Antunes DE. Revisiting primary neural leprosy: Clinical, serological, molecular, and neurophysiological aspects. PLoS Negl Trop Dis. 2017;11(11):e0006086. 
3. Anonim. Buku register Kunjungan Sub Divisi Morbus Hansen, Poliklinik Kulit dan Kelamin Rumah Sakit Umum Pusat Sanglah. Denpasar; 2015-2017.

4. Kumar Bhushan. Pure or primary neuritic leprosy. Lepr Rev. 2016;87:450-5

5. Van Brakel WH, Sihombing B, Djarir H. Disability in people affected by leprosy: the role of impairment, activity, social participation, stigma and discrimination. Glob. Health Action. 2012;5:18394.

6. James W, Dirk M, Timothy G. Hansen's Disease. Dalam: Andrews' Disease of the skin. Edisi ke-12. Philadelphia: Elsevier; 2016.h.331-41.
7. Banshal Rames. Leprosy. Essentials in Dermatology, Venereology \& Leprology. New Delhi: Jaypee Brothers; 2015.h.461-80.

8. Verdy, Arief B, Agnes S. Lepra tipe neural murni. Yogyakarta: BIKKK - Berkala Ilmu Kesehatan Kulit dan Kelamin - Periodical of Dermatology and Venereology leprae. 2015;27:421-41.

9. Rao PN, Suneetha S. Pure neuritic leprosy: Current status and relevance. Indian $\mathrm{J}$ Dermatol Venereol Leprol. 2016;82:252-61. 